Gut, 1967, 8, 454

\title{
Zinc and manganese levels in serum and liver after alcohol feeding and development of fatty cirrhosis in rats ${ }^{1}$
}

\author{
ANTHONY J. BARAK, HARRIET C. BECKENHAUER, AND FELIX J. KERRIGAN \\ From the Special Laboratory of Nuclear Medicine and Biology, Veterans Administration Hospital, \\ Omaha, Nebraska, U.S.A.
}

EDITORIAL COMMENT In this experiment, alcohol feeding and choline deficiency produced different effects on zinc and manganese levels in the liver, though these changes could not be correlated with the ability of the liver to detoxicate ammonia. It is suggested that this different effect on trace metals may explain some of the differences between the two types of cirrhosis produced experimentally by alcohol and by choline deficiency.

Contrary to earlier theories, several investigators (Vallee, 1966; Isselbacher and Greenberger, 1964; Lieber, 1963) believe that alcohol itself must be considered as an aetiological agent in the pathogenesis of the alcoholic fatty liver. The biochemical insult produced by ethyl alcohol which eventually results in Laennec's cirrhosis is still not understood. For many years experimenters have shown that fatty livers and an experimental type of cirrhosis can be produced in the livers of animals placed on a lowprotein, high-carbohydrate, high-fat, choline-deficient diet.

Whatever is the causal factor in cirrhosis, the two essential mechanisms to fail in the cirrhotic liver are the ammonia detoxification systems. When these fail, ammonia increases in the blood stream and is one of the factors in the development of hepatic coma. The first of these mechanisms is the KrebsHenseleit cycle which converts ammonia to urea. Two important enzymatic steps in the system (from ornithine to citrulline and from arginine to urea and ornithine) are activated by the trace metal $\mathrm{Mn}^{++}$.

A second ammonia detoxification mechanism which may fail in cirrhosis is a tangential reaction of the Krebs citric acid cycle. Here $\alpha$-ketoglutarate in the presence of ammonia is converted to glutamate by glutamic acid dehydrogenase activated by $\mathrm{Zn}^{++}$.

The present study was conducted to delineate the similarity and dissimilarity of alcohol feeding and a choline-deficient diet in producing biochemical lesions in reactions important to hepatic function and structure.

${ }^{1}$ This work was supported in part by a grant in aid from the Licensed Beverage Industries Incorporated, New York, New York.
MATERIALS AND METHODS

No attempt was made to restrict the metal intake of the Sprague-Dawley rats used in this study. The control rats were fed Rockland rat-mouse pellets and water ad libitum. The pellets showed an assay for manganese of $0.015 \%$ and $0.0063 \%$ for zinc. Alcohol-fed rats were placed on the same pellets but fed $15 \%$ ethyl alcohol in lieu of drinking water for three months. Fatty cirrhosis was produced in a third group of rats by placing them on a choline-deficient diet similar to that of Humoller and Zimmerman (1954) for a three-week period following nine weeks on Rockland rat pellets. After this experimental period specimens of serum and liver were saved from several rats of each of the three liver groups. These were analysed for levels of the trace metals zinc and manganese. Zinc in liver and serum was determined by the Haven (1964) neutron activation modification of the method of von Fischer and Leopoldi (1943). Serum manganese was determined by the neutron activation method of Haven, Haven, and Dunn (1966), and the tissue manganese was measured by the neutron activation procedure of Hahn, Haven, Tuma, Ogborn, and Quaife (1967).

As an ancillary study to the trace metal analysis, control livers and alcohol-fed livers were compared in their ability to remove added ammonia from the blood and produce urea nitrogen from added ammonium ion. This was accomplished by the isolated perfused liver technique of Miller, Bly, Watson, and Bale (1951) using the perfusate of Schimassek (1963). Ammonium acetate (8 millimoles per kilogram of body weight of the rat donating the liver) was added to the perfusate at the beginning of the experiment and the perfusion was conducted over a four-hour period.

In this study, in order to express ammonia removal, urea nitrogen production, and liver trace metal levels per gram of liver protein, liver protein levels were deter- 
mined by the method of Lowry, Rosebrough, Farr, and Randall (1951) using $1 \mathrm{~N}$ sodium hydroxide in place of the recommended $0 \cdot 1 \mathrm{~N}$ sodium hydroxide solution for dissolving liver protein.

\section{RESULTS}

The results of the analysis for serum zinc are shown in Table I. They show that rats on a choline-deficient diet had a statistically significant higher mean serum zinc level than rats on the control diet following the experimental period. Unfortunately serum zinc levels were not obtained from the alcohol-fed rats. As is seen in Table I, average serum levels of manganese were not significantly changed from normal rat serum levels by alcohol feeding but were lowered only a slight degree with the choline-deficient diet.

Table II shows that on a wet weight basis liver zinc was lowered in both fatty as well as alcohol-fed

TABLE I

TRACE METAL LEVELS IN RAT SERA

\begin{tabular}{|c|c|c|c|c|}
\hline \multirow[t]{2}{*}{ Type } & \multirow[t]{2}{*}{$\begin{array}{l}\text { No of } \quad \text { Mean } \\
\text { Deter- } \\
\text { minations }\end{array}$} & \multirow[t]{2}{*}{$\begin{array}{l}\text { Range } \\
(\mu g . / m l .)\end{array}$} & \multirow[t]{2}{*}{ S.D. } & $\begin{array}{l}\text { Significant } \\
\text { Difference } \\
\text { from Controls }\end{array}$ \\
\hline & & & & $\mathbf{t}^{1}$ \\
\hline
\end{tabular}

\begin{tabular}{|c|c|c|c|c|c|c|}
\hline \multicolumn{7}{|l|}{ Zinc } \\
\hline Control & 9 & 1.62 & $1 \cdot 23-2 \cdot 13$ & 0.322 & & \\
\hline $\begin{array}{l}\text { Choline- } \\
\text { deficient }\end{array}$ & 6 & $2 \cdot 19$ & $1.63-2.85$ & 0.417 & 2.98 & 0.02 \\
\hline \multicolumn{7}{|l|}{ Manganese } \\
\hline $\begin{array}{l}\text { Control } \\
\text { Choline- }\end{array}$ & 23 & 0.005 & $0.002-0.012$ & 0.002 & & \\
\hline deficient & 11 & 0.004 & $0.001-0.007$ & 0.002 & $1 \cdot 83$ & $0 \cdot 10$ \\
\hline Alcohol-fed & 9 & 0.006 & $0.002-0.010$ & 0.002 & 0.232 & N.S. \\
\hline
\end{tabular}

TABLE II

TRACE METAL LEVELS IN RAT LIVERS

\begin{tabular}{|c|c|c|c|c|}
\hline \multirow[t]{2}{*}{ Type } & \multirow[t]{2}{*}{$\begin{array}{l}\text { No of Mean } \\
\text { Deter- } \\
\text { minations }\end{array}$} & \multirow[t]{2}{*}{ Range } & \multirow[t]{2}{*}{ S.D. } & $\begin{array}{l}\text { Significant } \\
\text { Difference } \\
\text { from Controls }\end{array}$ \\
\hline & & & & $\mathbf{t}$ \\
\hline
\end{tabular}

\begin{tabular}{|c|c|c|c|c|c|c|}
\hline \multicolumn{7}{|c|}{$Z$ inc ( $\mu$ g. $\mathrm{Zn} / \mathrm{g}$. wet wt.) } \\
\hline Control & 21 & $37 \cdot 8$ & $27 \cdot 2-45 \cdot 2$ & $5 \cdot 10$ & & \\
\hline Fatty & 12 & $31 \cdot 4$ & $24 \cdot 8-38 \cdot 4$ & 3.84 & $3 \cdot 77$ & 0.001 \\
\hline Alcohol-fed & 10 & $32 \cdot 2$ & $29 \cdot 8-34 \cdot 8$ & $1 \cdot 76$ & $3 \cdot 39$ & 0.01 \\
\hline \multicolumn{7}{|c|}{ Zinc ( $\mu$ g. Zn/g. protein) } \\
\hline Control & 21 & 215 & $160-263$ & $33 \cdot 3$ & & \\
\hline Fatty & 12 & 212 & $155-243$ & $31 \cdot 2$ & 0.241 & N.S. \\
\hline Alcohol-fed & 10 & 170 & $150-197$ & $12 \cdot 9$ & $4 \cdot 04$ & 0.001 \\
\hline \multicolumn{7}{|c|}{ Manganese ( $\mu$ g. Mn/g. wet wt.) } \\
\hline Control & 22 & $2 \cdot 30$ & $1.93-2.74$ & $0 \cdot 20$ & & \\
\hline Fatty & 17 & $1 \cdot 18$ & $0 \cdot 86-1 \cdot 49$ & $0 \cdot 18$ & $17 \cdot 4$ & 0.001 \\
\hline Alcohol-fed & 10 & $2 \cdot 60$ & $2 \cdot 22-2 \cdot 98$ & 0.25 & $3 \cdot 58$ & 0.002 \\
\hline \multicolumn{7}{|c|}{ Manganese ( $\mu \mathrm{g} . \mathrm{Mn} / \mathrm{g}$. protein) } \\
\hline Control & 22 & $12 \cdot 7$ & $10 \cdot 2-15 \cdot 4$ & $1 \cdot 20$ & & \\
\hline Fatty & 17 & 8.3 & $6 \cdot 80-10 \cdot 1$ & 0.97 & $12 \cdot 1$ & 0.001 \\
\hline Alcohol-fed & 10 & $13 \cdot 3$ & $11 \cdot 6-15 \cdot 1$ & $1 \cdot 48$ & $1 \cdot 28$ & N.S. \\
\hline
\end{tabular}

livers. One would expect this in fatty livers because of the infiltration of fat into the tissue. However, one would not expect a deficiency in the alcohol-fed livers which were not fatty and quite normal in gross appearance. When the liver zinc levels are expressed on a microgram per gram of liver protein basis a somewhat different picture is obtained. On this basis (Table II) the fatty livers do not show a zinc deficiency but the alcohol-fed livers demonstrate a significantly lower mean value for zinc.

Table II demonstrates that the fatty livers produced in this study have a highly significant deficiency in manganese when levels are expressed on a wetweight basis. On this same basis liver manganese appears slightly elevated above the control livers in the alcohol-fed group. Expressing these results per gram of liver protein (Table II) the alcohol-fed livers are found to be comparable to the controls but the deficiency of manganese in the fatty livers is very apparent.

The results from the isolated liver perfusion studies conducted on normal rat livers and alcoholfed livers are shown in Table III. Although the difference between alcohol-fed and normal do not show a statistically significant difference when tested, the data indicate that alcohol-fed livers are at least as capable of removing added ammonium ion from $190 \mathrm{ml}$. of perfusate during the first hour of perfusion as normal livers. At present the significance of this is not understood, nor is the mechanism of ammonia removal from the blood stream thoroughly understood. It may or may not be related to the ammonia detoxification mechanisms of the

TABLE III

AMMONIA REMOVED BY PERFUSED RAT LIVERS IN ONE HOUR

\begin{tabular}{lccc} 
Liver & Supplement & $\begin{array}{l}\text { Per Gram } \\
\text { Liver Protein } \\
(u M / 190 \text { ml. })\end{array}$ & $\begin{array}{l}\text { Average } \\
(u M / 190 m l .)\end{array}$ \\
\hline Normal & $\mathrm{NH}_{4}$ acetate & 842 & \\
Normal & $\mathrm{NH}_{4}$ acetate & 623 & \\
Normal & $\mathrm{NH}_{4}$ acetate & 597 & 687 \\
Alcohol-fed & $\mathrm{NH}_{4}$ acetate & 939 & \\
Alcohol-fed & $\mathrm{NH}_{4}$ acetate & 851 & 864 \\
Alcohol-fed & $\mathrm{NH}_{4}$ acetate & 802 & 862
\end{tabular}

TABLE IV

UREA NITROGEN PRODUCTION BY PERFUSED RAT LIVER IN FOUR HOURS

\begin{tabular}{llcc} 
Liver & Supplement & $\begin{array}{l}\text { Per Gram } \\
\text { Liver Protein } \\
(u M / 190 \mathrm{ml} .)\end{array}$ & $\begin{array}{c}\text { Average } \\
(\text { uM/190 ml. })\end{array}$ \\
\hline Normal & $\mathrm{NH}_{4}$ acetate & 1,349 & \\
Normal & $\mathrm{NH}_{4}$ acetate & 1,252 & 1,249 \\
Normal & $\mathrm{NH}_{4}$ acetate & 1,147 & \\
Alcohol-fed & $\mathrm{NH}_{4}$ acetate & 1,584 & 1,306 \\
Alcohol-fed & $\mathrm{NH}_{4}$ acetate & 1,067 & 1,268 \\
Alcohol-fed & $\mathrm{NH}_{4}$ acetate & 1,268
\end{tabular}


liver and is only one means of studying liver function. One other parameter of determining liver function is urea nitrogen production when the liver is challenged with ammonia. When the alcohol-fed livers were challenged with ammonium acetate (Table IV) urea nitrogen production was as great as with the normal livers.

\section{DISCUSSION}

These data indicate that alcohol feeding by some unknown mechanism brings about a lowering in zinc content in the liver. This finding is in accord with the report by Vallee, Warren, Bartholomay, and Hoch (1959) who have shown a similar phenomenon in necropsied specimens of liver from cirrhotic patients. The fact that alcohol feeding does not affect the level of liver Mn, and, as shown by the liver perfusion experiments, does not lower the ability of the liver to remove ammonia from the blood stream or produce urea indicates that ethyl alcohol at these levels does not insult the Krebs-Henseleit cycle.

It appears that the biochemical lesion produced in the urea cycle is brought on by the lack of dietary factors in the choline-deficient diet. This is evident from the work of Burke and Miller (1956) and Barak and Beckenhauer (1966) who have demonstrated that urea production is hampered in experimental fatty livers produced by a choline-deficient diet. This may or may not be due to the intrinsic deficiency of manganese also brought on by the choline-deficient diet. The deficiency of manganese apparently is brought on by some unknown mechanism. It, indeed, is not due to a general body deficiency produced by the choline-deficient diet because this diet, according to Table II, maintained adequate serum manganese levels.

Lowering of zinc levels in the liver apparently does not affect its ability to remove ammonia from the blood stream or produce urea nitrogen. Even though zinc is involved in an ammonia detoxification system of the liver (the conversion of $\alpha$-ketoglutarate and $\mathrm{NH}_{3}$ to glutamic acid through the medium of glutamic acid dehydrogenase) a deficiency of zinc in the liver did not reflect itself in the removal of ammonia from the blood perfusate in the perfused alcohol-fed liver.

Although a choline-deficient diet increased the serum zinc level in rats, it did not affect the liver zinc-protein ratio in these livers. It appears from this, and the data on manganese, that normal or excessive availability of trace metals does not govern the metal-protein ratio in the liver. Even though insults bring about trace metal deficiencies, nothing is evident from these data to show what controls proper metal and protein balance.
With both manganese and zinc serving in the organism as enzyme activators, it is not surprising to see hepatic function altered in a deficiency of these metals. With $\mathrm{Zn}$ activating such enzymes as glutamic acid dehydrogenase, glycyl-glycyl dipeptidase and tripeptidase, and with $\mathrm{Zn}$ or $\mathrm{Mn}$ activating alanylglycine dipeptidase, leucyle-glycine dipeptidase, glycyl-leucine dipeptidase, and amino peptidase (Vallee, 1959), it would not be surprising to see structure altered when enzymatic protein anabolism is disturbed by trace metal deficiency. Keeping these facts in mind, it is tempting to offer these data as an explanation as to why experimental cirrhosis produced by a choline deficiency is morphologically and clinically different from alcoholic or Laennec's cirrhosis.

Because alcohol shows one effect and dietary factors show another effect in this study, it is indeed easy to speculate on the fact that each causative factor may possibly contribute its own respective lesion or lesions to produce a true Laennec's type cirrhosis.

\section{SUMMARY}

This investigation has shown that the two agents believed to be responsible for the development of Laennec's cirrhosis each individually produce biochemical deficiencies which may act synergistically to produce this malady. Alcohol feeding, together with a complete diet, produced a deficiency of liver zinc. This trace metal is known to activate enzymes related to protein synthesis. A choline-deficient diet was shown to produce a deficiency in liver manganese, an enzyme activator related mostly to hepatic function.

\section{REFERENCES}

Barak, A. J., and Beckenhauer, H. C. (1966). Studies of isolated perfused rat livers. I. Effect of arginine and glutamate on ammonia metabolism in normal, fatty, and precancerous livers. Biochem. Pharmacol., 15, 1295-1302.

Burke, W. T., and Miller, L. L. (1956). Biochemical changes during experimental carcinogenesis. I. Amino acid metabolism in perfused livers of rats with cirrhosis and azo dye-fed rats. Cancer Res., 16, 330-337.

von Fischer, H., and Leopoldi, G. (1943). Kolorimetrische Schnellmethods für die Zinkbestimmung in Aluminium-umschmelzlegierunger nach dem Dithizonverfahren. $Z$. Aluminum, 25 356-357.

Hahn, H. J., Haven, M. C., Tuma, D. J., Ogborn, R. E., and Quaife, M. A. (1967). Determination of manganese in tissue by neutron activation analysis. $\mathrm{Nucl}$. Appl., in the press.

Haven, M. C. (1964). Neutron activation analysis of zinc in biologica samples. Master's dissertation, Creighton University, Omaha Nebraska.

- Haven, G. T., and Dunn, A. L. (1966). Simultaneous determination of calcium, copper, manganese, and magnesium in serum by neutron activation analysis. Anal. Chem., 38, 141-143.

Humoller, F. L., and Zimmerman, H. J. (1954). Factors influencing betaine aldehyde oxidase activity of rat livers. Amer. $J$ Physiol., 177, 279-284. 
Isselbacher, K. J., and Greenberger, N. J. (1964). Metabolic effects of alcohol on the liver. New Engl. J. Med., 270, 351-356, 403-410.

Lieber, C. S. (1963). Pathogenesis of hepatic steatosis. Gastroenterology, 45, 760-764.

Lowry, O. H., Rosebrough, N. J., Farr, A. L., and Randall, J. (1951). Protein measurement with the folin phenol reagent. J. biol. Chem., 193, 265-275.

Miller, L. L., Bly, C. G., Watson, M. L., and Bale, W. F. (1951). The dominant role of the liver in plasma protein synthesis. J. exp. Med., 94, 431-453.
Schimassek, H. (1963). Metabolite des Kohlenhydratesloffwechsel der isoliert perfundierten Rattenleber. Biochem. Z., 336, 460-467.

Vallee, B. L. (1966). Alcohol metabolism and metalloenzymes. Int. Forum, 14, 72-74.

(1959). Biochemistry, physiology and pathology of zinc. Physiol. Rev., 39, 443-490.

-, Warren, E. C. W., Bartholomay, A. F., and Hoch, F. L. (1959). Zinc metabolism in hepatic dysfunction. Ann. intern. Med., 50, 1077-1091. 